\title{
Pertumbuhan dan Perkembangan Cabai Keriting (Capsicum annuum L.) secara In Vitro pada beberapa Konsentrasi BAP dan IAA
}

\author{
Growth and Development of In Vitro Curly Pepper (Capsicum annuum L.) \\ in some Concentration BAP and IAA
}

\author{
Verdy Soelaiman, Andri Ernawati*
}

Departemen Agronomi dan Hortikultura, Fakultas Pertanian, Institut Pertanian Bogor (Bogor Agricultural University), J1. Meranti, Kampus IPB Darmaga, Bogor 16680, Indonesia

Telp.\&Faks.62-251-8629353 e-mail agronipb@indo.net.id

\begin{abstract}
Curly red pepper (Capsicum annuum $L$.) is one of the crops that are important and widely cultivated in Indonesia. The purpose of this research was to determine the effect of the use of plant growth regulators BAP and IAA in various doses on the growth and development of curly red peppers in vitro. This research was conducted on March until October 2011 in Tissue Culture Laboratory Department of Agronomy and Horticulture, Faculty of Agriculture, Bogor Agricultural University. This research using Randomized Complete Design with combination of plant growth reguators as the factor. The results showed that combinations of growth regulators significantly influenced root induction, high growth, number of leaves, callus and shoot multiplication. Plant growth regulator combination of $0 \mathrm{mg} \mathrm{L-1} \mathrm{BAP}+1 \mathrm{mg} L-1$ IAA was very good treatment in inducing roots. Combination of $2 \mathrm{mg}$ L-1 BAP + $0.2 \mathrm{mg}$ L-1 IAA effect high growth and shoot induction. Combination of $1 \mathrm{mg} L-1$ BAP $+0 \mathrm{mgL}-1$ IAA was the best treatment in increasing number of leaves. While for callus and multiplication, the best treatment was combination of $4 \mathrm{mg} L-1$ BAP $+0 \mathrm{mg} L-1$ IAA .
\end{abstract}

Keyword: induction, growth regulators, pepper,plant.

\begin{abstract}
ABSTRAK
Cabai keriting (Capsicum annuum $L$.) adalah satu dari komoditas yang penting dan ditanam secara luas di Indonesia. Tujuan dari penelitian ini untuk mengetahui pengaruh penggunaan zat pengatur tumbuh BAP dan IAA dalam beberapa konsentrasi pada pertumbuhan dan perkembangan cabai merah keriting secara in vitro. Penelitian ini dilaksanakan pada bulan Maret - Oktober 2011 di Laboratorium Kultur Jaringan Tanaman, Departemen Agronomi dan Hortikultura, Fakultas Pertania, IPB. Penelitian ini menggunakan RAL dengan satu faktor yaitu zat pengatur tumbuh. Hasil penelitian menunjukkan bahwa kombinasi zat pengatur tumbuh mempengaruhi induksi akar, pertambahan tinggi, jumlah daun, kalus dan multiplikasi tunas. Kombinasi ZPT 0 $m g$ L-1 BAP $+1 \mathrm{mg}$ L-1 IAA sangat baik untuk menginduksi akar. Kombinasi of $2 \mathrm{mg}$ L-1 BAP $+0.2 \mathrm{mg}$ L-1 IAA mempengaruhi pertumbuhan tinggi dan induksi tunas. Kombinasi $1 \mathrm{mg} L-1$ BAP $0 \mathrm{mgL-1}$ IAA adalah perlakuan terbaik untuk meningkatkan jumlah daun. Sedangkan untuk kalus dan multiplikasi tunas perlakuan terbaik adalah $4 m g$ L-1 BAP + $0 m g$ L-1 IAA.
\end{abstract}

Kata kunci: cabai keriting, induksi, zat pengatur tumbuh

\section{PENDAHULUAN}

Cabai merah keriting (Capsicum annuum L.) merupakan salah satu hasil pertanian yang penting

\footnotetext{
*Penulis untuk korespondensi. e-mail: andri.ernawati@gmail.com
}

dan banyak dibudidayakan di Indonesia. Buah cabai memiliki aroma, rasa pedas dan warna yang spesifik, sehingga banyak digunakan oleh masyarakat sebagai rempah dan bumbu masakan. Seiring dengan pertambahan penduduk yang pesat dan berkembangnya industri makanan, maka kebutuhan cabai di Indonesia 
pun meningkat.

Produktivitas cabai di Indonesia saat ini masih tergolong rendah. Selain itu, permasalahan yang dihadapi adalah mutu cabai yang kurang baik. Faktor-faktor yang menyebabkan rendahnya produktivitas cabai Indonesia antara lain penggunaan benih yang kurang bermutu, teknik budidaya yang belum efisien dan penanaman kultivar cabai yang tidak tahan terhadap hama serta penyakit. Perbaikan varietas dari cabai merah keriting ini seperti pertumbuhan dan perkembangan tanaman yang baik serta ketahanan terhadap penyakit dapat dilakukan dengan teknik kultur jaringan. Teknik kultur jaringan dapat meningkatkan nilai tambah program pemuliaan tanaman, terutama dalam usaha peningkatkan kualitas dan kuantitas produksi cabai merah keriting secara optimal.

Penelitian ini menggunakan teknik penanaman in vitro. Penanaman cabai in vitro dapat dilakukan dengan menggunakan berbagai bagian tanaman seperti batang muda, tunas pucuk, atau bagian kecambah. Keberhasilan dalam menginduksi tunas dari eksplan secara in vitro dipengaruhi oleh beberapa faktor diantaranya adalah zat pengatur tumbuh yang digunakan dan kondisi ruang kultur jaringan (George and Sherington, 1984). Tanaman cabai dalam regenerasi tunas secara in vitro dapat dilakukan dari berbagai bagian yaitu kotiledon (Ebida and $\mathrm{Hu}, 1993$; Hyde and Phillips, 1996), hipokotil (Ebida and Hu, 1993; Fari and Czako, 1981), atau daun muda. Induksi tunas dari berbagai eksplan umumnya dilakukan dalam media kultur jaringan yang mengandung BAP dengan atau tanpa IAA. IAA ditambahkan ke dalam media dengan BAP untuk meningkatkan frekuensi pembentukan tunas.

BAP juga dilaporkan lebih efektif untuk menginduksi pembentukan tunas cabai merah secara in vitro dibanding 2-iP atau kinetin (Siregar et al., 1997). Dengan demikian, penelitian lebih lanjut berguna dalam menentukan pengaruh zat pengatur tumbuh (BAP dan IAA) terhadap perkembangan dan pertumbuhan yang terbaik untuk cabai merah secara in vitro. Pertumbuhan serta perkembangan dalam induksi akar dan tunas terhadap cabai secara in vitro. Tujuan dari percobaan ini adalah untuk mengetahui pengaruh dari penggunaan zat pengatur tumbuh BAP dan IAA dalam berbagai kosentrasi terhadap pertumbuhan dan perkembangan cabai merah keriting secara in vitro.

\section{BAHAN DAN METODE}

\author{
Penelitian ini dilaksanakan di Laboratorium \\ Kultur Jaringan, Departemen Agronomi dan
}

Hortikultura, Fakultas Pertanian, Institut Pertanian Bogor. Penelitian ini dilaksanakan pada bulan Maret Oktober 2011. Bahan tanaman yang digunakan berupa benih komersial tanaman cabai merah keriting hibrida TM888. Media yang digunakan adalah MS (Murashige dan Skoog). Zat pengatur tumbuh meliputi BAP dan IAA. Bahan lain yang digunakan adalah agaragar, gula, alkohol, bahan kimia komponen media MS, Betadine, aquadest dan spritus. Bahan untuk sterilisasi adalah deterjen, Clorox/bayclin (sodium hypoklorit), agrept (bakterisida), dithane (fungisida), dan air steril.

Berikut adalah perlakuan dari kombinasi zat pengatur tumbuh (BAP dan IAA) dalam beberapa taraf kosentrasi:

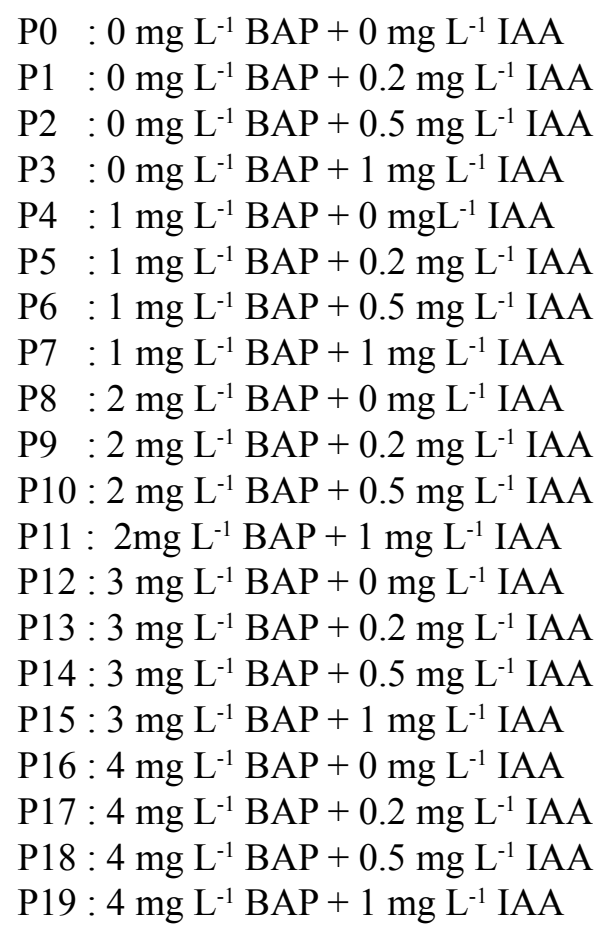

\section{HASIL DAN PEMBAHASAN}

Penelitian dimulai dengan penyiapan bahan tanam yang berasal dari benih cabai. Benih cabai yang digunakan adalah jenis cabai merah keriting hibrida TM888. Bibit ditanam dalam media penunasan berupa MS0. Setelah benih bertunas menjadi eksplan, kemudian dilakukan subkultur pada media perlakuan yang terdiri dari 20 kombinasi zat pengatur tumbuh antara BAP dan IAA. Perlakuan yang dilakukan berjumlah 20 perlakuan dengan 10 ulangan.

Pada perlakuan, eksplan yang digunakan dalam kultur adalah berupa tunas pucuk. Banyaknya eksplan yang digunakan berjumlah 1 eksplan per botol kultur sehingga memudahkan pengamatan dan mengurangi persaingan dalam perbutan hara tanaman. Eksplan yang digunakan berupa eksplan yang dipilih 
keseragamannya untuk meminimalkan ragam dalam perlakuan.

\section{Pengaruh Kombinasi ZPT terhadap Induksi Akar}

Tolok ukur dari induksi akar merupakan salah satu parameter dari pertumbuhan dan perkembangan tanaman. Induksi akar dapat dipengaruhi dengan adanya penambahan zat pengatur tumbuh, khususnya pemberian zat pengatur tumbuh berupa auksin (IAA). Dengan penambahan auksin (IAA) ini dapat menginduksi pertumbuhan akar dengan cepat.

Gambar 1 menunjukkan pengaruh dari pemberian kombinasi zat pengatur tumbuh (BAP dan IAA) terhadap induksi akar. Pemberian zat pengatur tumbuh memberikan pengaruh yang sangat nyata terhadap induksi akar. Pada minggu pertama, perlakuan yang terbaik adalah perlakuan P1 yaitu kombinasi 0 mg L-1 BAP dan 0.2 mg L-1 IAA. Pada minggu kedua sampai dengan minggu keempat, perlakuan terbaik terdapat pada perlakuan $\mathrm{P} 2$ dengan kombinasi $0 \mathrm{mg} \mathrm{L}-$ 1 BAP dan $0.5 \mathrm{mg} \mathrm{L}-1$ IAA.

Selanjutnya, jika di lihat pada minggu keempat sampai dengan minggu terakhir pengamatan (12 minggu setelah kultur $=$ MSK $)$, dapat diketahui bahwa perlakuan yang terbaik adalah pada P3 yaitu kombinasi antara $0 \mathrm{mg}$ L-1 BAP dan $1 \mathrm{mg}$ L-1 IAA. Hal ini disebabkan oleh kosentrasi auksin yang tinggi pada perlakuan ini. Secara umum, perlakuan yang terbaik dalam menginduksi akar adalah perlakuan P3 (0 mg L-1 BAP + 1 mg L-1 IAA). Namun jika di berikan dengan penambahan sitokinin (BAP), maka induksi akar akan tidak berbeda nyata. Hal ini disebabkan karena sitokinin berfungsi sebagai zat pengatur tumbuh yang dapat menginduksi pembelahan

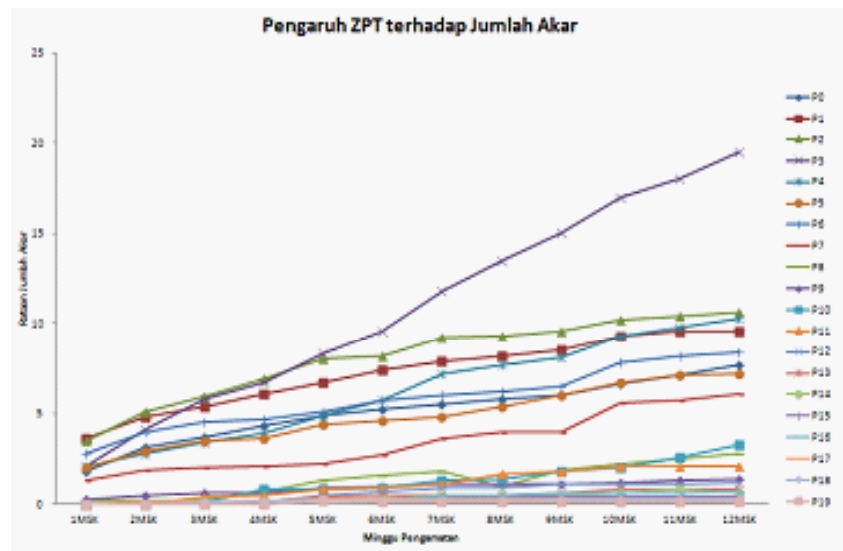

Gambar 1. Jumlah akar dari tunas pucuk cabai keriting in vitro pada beberapa kombinasi ZPT sel, mendorong poliferasi tunas dan diferensiasi tunas adventif dari organ tanaman dan sintesa protein (George and Sherington, 1984). Pada perlakuan P3 ini dapat dilihat bahwa pertumbuhan induksi akar yang terjadi sangat signifikan.

Dengan penambahan kombinasi zat pengatur tumbuh BAP dan IAA ini memberikan pengaruh yang sangat nyata terhadap induksi akar. Perlakuan yang terbaik dalam menginduksi akar yaitu dengan perlakuan $\mathrm{P} 3$ kombinasi antara $0 \mathrm{mg}$ L-1 BAP dan $1 \mathrm{mg}$ L-1 IAA.

\section{Pengaruh Kombinasi ZPT terhadap Pertambahan Tinggi Tunas Pucuk}

Pertambahan tinggi dapat dipengaruhi dengan adanya penambahan zat pengatur tumbuh, khususnya pemberian zat pengatur tumbuh berupa sitokinin (BAP) yang dapat merangsang pertumbuhan tinggi eksplan cabai dengan cepat.

Gambar 2 menunjukkan pengaruh dari pemberian kombinasi zat pengatur tumbuh (BAP dan IAA) terhadap tolok ukur pertumbuhan tinggi. Pemberian zat pengatur tumbuhmemberikan pengaruh yang sangat nyata terhadap pertumbuhan tinggi.

Dilihat dari gambar 2, terjadi peningkatan tinggi eksplan cabai dari awal perlakuan sampai dengan akhir pengamatan. Pada minggu pertama, perlakuan yang terbaik adalah perlakuan P8, yaitu kombinasi $2 \mathrm{mg} \mathrm{L}^{-1}$ BAP dan $0 \mathrm{mg} \mathrm{L}^{-1}$ IAA. Selanjutnya dapat dilihat, pada minggu kedua hingga minggu ke11 bahwa perlakuan yang terbaik adalah perlakuan P9 yaitu kombinasi antara $2 \mathrm{mg} \mathrm{L}^{-1} \mathrm{BAP}$ dan $0,2 \mathrm{mg} \mathrm{L}^{-1}$ IAA. Namun perlakuan P19 (4 mg L ${ }^{-1}$ BAP dan 1 mg L $\mathrm{L}^{-1}$ IAA) tidak mengalami pertumbuhan yang cepat, hal ini dapat disebabkan oleh konsentrasi dari BAP dan IAA yang tinggi, sehingga tidak berpengaruh nyata terhadap perkembangan tanaman cabai secara in vitro ini. Jika dilihat pada akhir pengamatan terjadi perubahan, perlakuan terbaik pada perlakuan P4.

Perlakuan yang terbaik dalam menginduksi pertumbuhan tinggi eksplan cabai secara in vitro ini adalah perlakuan P9 $\left(2 \mathrm{mg} \mathrm{L}^{-1}\right.$ BAP dan $0.2 \mathrm{mg}$ $\mathrm{L}^{-1}$ IAA). Kombinasi antara BAP dan IAA pada media perlakuan ini cenderung menginduksi tunas dengan baik dibandingkan media dengan BAP saja, sehingga pertambahan tinggi eksplan pun sangat nyata terlihat. Hal ini sejalan dengan penelitian yang sudah dilaporkan (Fari and Czako, 1981; Hyde and Philips, 1996) bahwa ternyata kosentrasi BAP yang digunakan untuk induksi tunas dan pertambahan tinggi bervariasi antara $2-5 \mathrm{mg} \mathrm{L}^{-1}$ dan tergantung dari varietas cabai yang digunakan. 


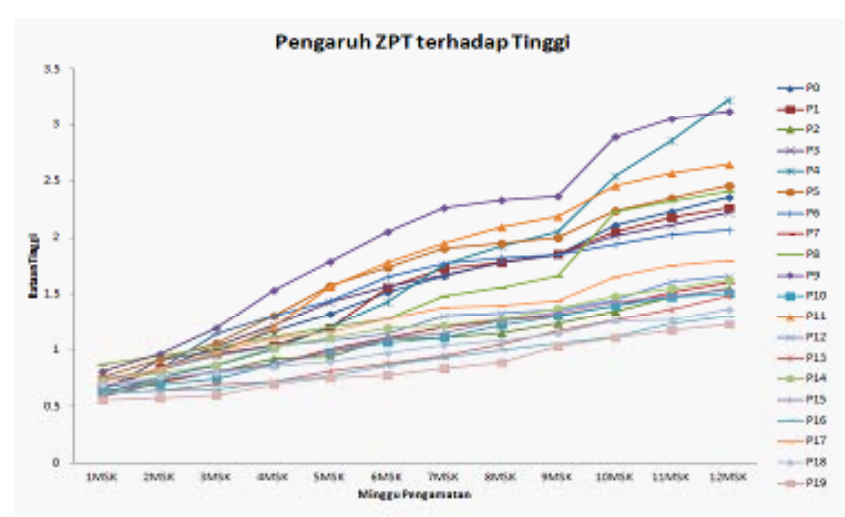

Gambar 2. Tinggi tunas pucuk cabai keriting in vitro pada beberapa kombinasi ZPT

\section{Pengaruh Kombinasi ZPT terhadap Jumlah Daun}

Semakin banyak daun yang terdapat pada eksplan, semakin baik proses fotosintesis pada eksplan. Hal ini dapat menandakan pertumbuhan dan perkembangan dari eksplan yang ditanam.

Gambar 3 menjelaskan tentang pengaruh dari

Tabel 1. Persentase kalus dan multiplikasi tunas pucuk cabai keriting in vitro pada beberapa kombinasi ZPT

\begin{tabular}{lrcc}
\hline Perlakuan & \multicolumn{3}{c}{ Frekuensi eksplan } \\
\cline { 2 - 4 } & Berkalus & Multiplikasi & $\begin{array}{c}\text { Rata-rata } \\
\text { jumlah }\end{array}$ \\
\hline P0 & 0 & 0 & 0 \\
P1 & 0 & 0 & 0 \\
P2 & 0 & 0 & 0 \\
P3 & 0 & 0 & 0 \\
P4 & 50 & 0 & 0 \\
P5 & 60 & 0 & 0 \\
P6 & 50 & 0 & 0 \\
P7 & 50 & 0 & 0 \\
P8 & 60 & 0 & 0 \\
P9 & 60 & 0 & 0 \\
P10 & 70 & 0 & 0 \\
P11 & 60 & 0 & 0 \\
P12 & 70 & 20 & 2 \\
P13 & 80 & 10 & 3 \\
P14 & 80 & 10 & 2 \\
P15 & 70 & 10 & 4 \\
P16 & 100 & 30 & 5 \\
P17 & 90 & 20 & 3 \\
P18 & 80 & 20 & 4 \\
P19 & 90 & 20 & 3 \\
\hline
\end{tabular}

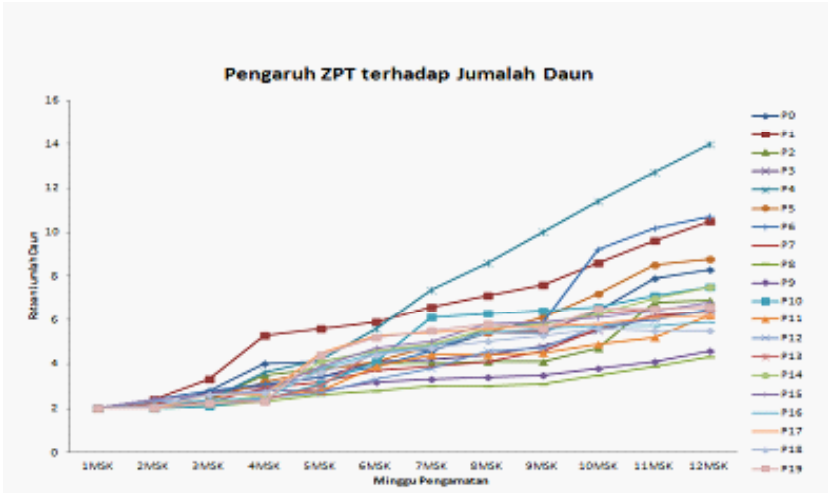

Gambar 3. Jumlah daun pada tunas pucuk cabai keriting in vitro pada beberapa kombinasi ZPT

pemberian kombinasi zat pengatur tumbuh (BAP dan IAA) dengan beberapa taraf terhadap perkembangan jumlah daun pada eksplan tanaman cabai ini. Pada minggu pertama pengamatan, tidak terjadi perubahan pada setiap perlakuan. Pada minggu kedua, terjadi peningkatan rataan jumlah daun. Perlakuan yang terbaik pada minggu kedua ini adalah perlakuan $\mathrm{P} 6$ yaitu $1 \mathrm{mg} \mathrm{L}^{-1}$ BAP dan $0.5 \mathrm{mg} \mathrm{L}^{-1}$ IAA.

Selanjutnya jika dilihat pada minggu ketiga sampai dengan minggu keenam, terjadi perubahan peningkatan jumlah daun. Perlakuan yang terbaik adalah perlakuan P1 (0 mg L-1 BAP dan $0.2 \mathrm{mg} \mathrm{L}^{-}$ ${ }^{1}$ IAA). Setelah itu, pada minggu ketujuh sampai dengan akhir pengamatan, peningkatan jumlah daun yang lebih signifikan pada perlakuan $\mathrm{P} 4\left(1 \mathrm{mg} \mathrm{L}^{-1}\right.$ BAP dan $0 \mathrm{mg} \mathrm{L}^{-1}$ ). Hal ini dapat dipengaruhi dengan sitokinin yang diberikan pada perlakuan. Dengan adanya sitokinin, dapat menginduksi terbentuknya tunas dengan pertambahan jumlah daun.

Perlakuan yang terbaik untuk perkembangan jumlah daun pada eksplan cabai ini adalah pada perlakuan P4. Hal ini dapat dilihat dari perkembangan yang sangat nyata dengan kenaikan yang signifikan pada Gambar 3. Dengan adanya kombinasi zat pengatur tumbuh antara BAP dan IAA ini, menberikan pengaruh yang sangat nyata terhadap peningkatan jumlah daun. peningkatan jumlah daun ini juga mempengaruhi proses fotosintesis pada tanaman yang semakin baik.

\section{Pengaruh Kombinasi ZPT terhadap Pertumbuhan Kalus dan Multiplikasi Tunas}

BAP berperan dalam mendorong proses pembelahan sel, poliferasi tunas dan penghambatan pertumbuhan akar (Pierik, 1987). Dalam penelitian ini diduga terdapat hubungan sinergis antara BAP dan 
IAA dalam mendorong pembelahan dan pembesaran sel yang mengakibatkan terjadinya pengkalusan dan multiplikasi pada eksplan yang di tanam.

Tabel 1 dapat dilihat semakin tinggi kosentrasi BAP yang diberikan, semakin tinggi juga frekuensi eksplan yang berkalus dan semakin tinggi pula yang mengalami multiplikasi. Pada tabel juga dapat dilihat bahwa perlakuan terbaik untuk pengkalusan dan multiplikasi adalah perlakuan P16. Perlakuan P16 (4 mg L${ }^{-1}$ BAP dan $0 \mathrm{mg} \mathrm{L}^{-1} \mathrm{IAA}$ ) sangat nyata dalam menginduksi kalus dan multiplikasi.

Jika dilihat dari rata-rata jumlah tunas multiplikasi, perlakuan P16 memiliki rata-rata jumlah tunas yang lebih banyak. Hal ini juga disebabkan oleh penambahan zat pengatur tumbuh berupa sitokinin (BAP) yang memberikan pengaruh nyata terhadap poliferasi tunas dan diferensiasi tunas adventif. Rata-rata jumlah tunas pada eksplan yang mengalami multiplikasi tunas rata-rata tertinggi pada pelakuan P16 dengan jumlah rata-rata tunas sebanyak 5 tunas. Dapat disimpulkan, dengan kombinasi zat pengatur tumbuh yang sesuai dapat meningkatkan jumlah eksplan yang berkalus dan eksplan yang mengalami multiplikasi yang dapat dilihat pada perlakuan P16.

\section{KESIMPULAN}

Kombinasi zat pengaruh tumbuh berpengaruh sangat terhadap pertumbuhan dan perkembangan cabai secara in vitro. Perlakuan P3 $\left(0 \mathrm{mg} \mathrm{L}^{-1}\right.$ BAP dan $1 \mathrm{mg} \mathrm{L}^{-1}$ IAA) dapat menginduksi akar dengan baik. Kombinasi dari perlakuan P9 $\left(2 \mathrm{mg} \mathrm{L}^{-1}\right.$ BAP dan $0,2 \mathrm{mg} \mathrm{L}^{-1} \mathrm{IAA}$ ) berpengaruh sangat nyata dalam induksi tunas yang menyebabkan tinggi eksplan yang meningkat dengan baik. Jika dilihat dari jumlah daun, perlakuan P4 (1 mg L-1 BAP dan $\left.0 \mathrm{mg} \mathrm{L}^{-1} \mathrm{IAA}\right)$ merupakan perlakuan yang terbaik. Sedangkan dalam pengkalusan dan multiplikasi eksplan, semakin tinggi konsentrasi zat pengatur tumbuh yang diberikan (khususnya kosentrasi sitokinin yang tinggi), semakin tinggi pula persentase kalus dan multiplikasi yang terjadi. Perlakuan yang terbaik untuk pengkalusan dan multiplikasi adalah perlakuan P16 (4 $\mathrm{mg} \mathrm{L}^{-1}$ BAP dan $0 \mathrm{mg} \mathrm{L}^{-1}$ IAA).

\section{DAFTAR PUSTAKA}

Ebida, A.I., C.Y. Hu. 1993. In vitro morphogenetic responses and plant regeneration from pepper (Capsicum annuum L. cv. Early California Wonder) seedling explants. Plant Cell Rep. 13:107-110.

Fari, M., M. Czako. 1981. Relationship between position of morphogenetic response of pepper hypocotyls explants cultured in vitro. Scientia Horticulturae 15:207-213.

George, H.F., P. Sherington. 1984. Plant Propagation by Tissue Culture. Exegetic Public td, England.

Hyde, C.L., G.C. Phillips. 1996. Silver nitrate promotes shoot development and plant regeneration of pepper (Capsicum annuum L.) via organogenesis. In Vitro Cell Dev. Bio. 32:172-180.

Pierik, R.L.M. 1987. In Vitro Cultures of Higher Plant. Martinus - Nijhoff Publ. Dordrecht, Netherlands.

Siregar, E.B.M., S. Ramadiana, Sudarsono. 1997. Difficulties in including shoot regeneration from various explants in in vitro culture of hot pepper (Capsicum annuum. L.). International Biotechnology Conference. Jakarta, 17-19 Juni 1997 (Abstract). 